\title{
CT による骨折リスク評価
}

\section{産業医科大学放射線科学教室 准教授 \\ 靕条 隆敏}

骨粗鬆症は骨密度と骨質劣化により骨強度が低下した状態であり、大腿骨近位部骨折などにより著 しい生活の質（QOL）低下をもたらし、健康寿命の維持に大きな影響をおよぼす。日常診療では、骨 粗鬆症診断基準として、2 重エネルギーエックス線吸収測定法（DXA）による骨密度が用いられてい るが、骨強度は骨質とも強く関連しているため、骨密度測定のみでは骨折リスクを十分に予測し得ない。

生活習慣病は骨密度に依存しない骨折リスクの上昇をもたらす。特に 2 型糖尿病では、骨密度が維 持されている骨折例が多い。慢性閉塞性肺疾患患者も骨折リスクが高く、胸椎圧迫骨折のリスクが高 くなることが知られている。CT は癌検出のみならず、肺気腫の有無や重症度を分類でき、撮像範囲の 骨折の有無や骨強度の評価も可能である。本シンポジウムでは、CT 用いた骨強度評価法を紹介し、 生活習慣病を中心に、低線量 CT を骨折リスクの早期診断に応用する取り組みについて述べる。 